Article

\title{
Modified Polyacrylic Acid-Zinc Composites: Synthesis, Characterization and Biological Activity
}

\author{
Mohammed Rafi Shaik, Mufsir Kuniyil, Mujeeb Khan, Naushad Ahmad, \\ Abdulrahman Al-Warthan, Mohammed Rafiq H. Siddiqui and Syed Farooq Adil * \\ Department of Chemistry, College of Science, King Saud University, P. O. Box 2455, Riyadh 11451, Saudi Arabia; \\ rafiskm@gmail.com (M.R.S.); mufsir@gmail.com (M.K.); kmujeeb@ksu.edu.sa (M.K.); \\ exactlykot@gmail.com (N.A.); awarthan@ksu.edu.sa (A.A.-W.); rafiqs@ksu.edu.sa (M.R.H.S.) \\ * Correspondence: sfadil@ksu.edu.sa; Tel.: +966-11-4670-439
}

Academic Editor: Derek J. McPhee

Received: 6 January 2016 ; Accepted: 25 February 2016 ; Published: 29 February 2016

\begin{abstract}
Polyacrylic acid (PAA) is an important industrial chemical, which has been extensively applied in various fields, including for several biomedical purposes. In this study, we report the synthesis and modification of this polymer with various phenol imides, such as succinimide, phthalimide and 1,8-naphthalimide. The as-synthesized derivatives were used to prepare polymer metal composites by the reaction with $\mathrm{Zn}^{+2}$. These composites were characterized by using various techniques, including NMR, FT-IR, TGA, SEM and DSC. The as-prepared PAA-based composites were further evaluated for their anti-microbial properties against various pathogens, which include both Gram-positive and Gram-negative bacteria and different fungal strains. The synthesized composites have displayed considerable biocidal properties, ranging from mild to moderate activities against different strains tested.
\end{abstract}

Keywords: polyacrylic acid; zinc; metal composite; biological activity

\section{Introduction}

The surge of interest in polymer science and engineering has been governed by the fact that there are multiple applications in various domains of daily life that can be explored for the new products formed. Improved performance and durability serve as a primary motive of the research. Among various polymers that are being studied, polyacrylic acid (PAA) has received significant attention due to its tremendous applications in several fields, including electrochemical [1], electronic [2], biomedical [3-6], and so on. It has been widely applied in various optical devices [7], as a solid electrolyte for lithium ion batteries, [8] in supercapacitors [9,10], as an ion exchanger [11], an efficient corrosion inhibitor [12] and eco-friendly coatings agent [13]. Furthermore, it has also been reported that the chemical stability of metal oxide nanoparticles in electronic and electrochemical devices could be improved by the use of PAA coatings [14]. Therefore, there is a growing interest in the development of PAA-based composites containing different oxide nanoparticles in a PAA matrix, such as $\mathrm{PAA}^{-\mathrm{TiO}_{2}}$ composites, etc. These types of composites have been extensively applied for various applications in solar cells [15], wastewater treatment [16], protective coatings [17], biomedical [18] and optical devices [19]. For instance, in a recent study, the $\mathrm{pH}$-sensitive $\mathrm{PAA}-\mathrm{SiO}_{2}$ composites were successfully used for the purpose of drug delivery [20]. Similarly, in other studies, it was revealed that the PAA is able to capture heavy metal ions at low concentrations, which can be used as a chelating material; hence, it can be utilized for the removal of toxic heavy metals from water [21].

Biomedical applications of various polymers and polymer-based materials, including polyacrylic acid (PAA) and its derivatives, have been extensively reported in the literature [22-24]. These materials 
are employed for the manufacturing of medical probes for analysis, hand-held water filters, surface coatings, fibrous disinfectants, and so on. Therefore, the biocidal property of the polymeric substance is also an important parameter, which has significant impact on various biological applications. For instance, Zauresh and coworkers carried out the synthesis of PAA complexes with streptomycin sulfate and the study of the antibacterial properties of PAA and their derivatives [25]. It was reported that the synthesized PAA complexes possessed improved antimicrobial property.

Gottenbos et al. [26] investigated the antimicrobial activity of poly(methacrylic acid) copolymers and described that electrostatic effects due to negatively-charged surfaces merely delay bacterial attachment and biofilm formation [26,27]. Other studies have revealed that polyacrylic acid based copolymers also showed excellent antimicrobial effects. For instance, in a recent report, it was revealed that cold plasma embedded acrylic acid on a poly(ethylene) surface produces a zone of inhibition for Staphylococcus aureus [28]. In another study, radiation embedded acrylic acid on poly(ethylene terephthalate) surfaces with $48 \mathrm{wt} \%$ acrylic acid decreased the integer of colony forming units (CFU) of Escherichia coli by $78 \%$ after 240 min [29]. Further, $40 \mathrm{wt} \%$ radiation embedded poly(methacrylic acid) on poly(propylene) surfaces decreased the progress of $\mathrm{S}$. aureus and Klebsiella pneumoniae by above $99 \%$ after $24 \mathrm{~h}$ [30]. Similarly, Yang et al. [31] noticed that the antimicrobial activity effect against Pseudomonas aeruginosa rises with increasing mass fraction (from 10\% to $40 \%$ ) of radiation embedded polyacrylic acid on poly(propylene) nonwoven material added to a bacterial suspension [31]. However, in all of these works, the researchers concentrated on various antimicrobial agents and stated that the polyacrylic acid grafted carrier polymer was antimicrobially active also.

The prospect of integrating antimicrobial cross-linkers into polyacrylic acid castoff in such devices might be a technique of decreasing dermatitis and smell from the bacterially-arbitrated analysis of urine. Interpenetrated polymer networks (IPN) have displayed certain potential as a method of integrating antimicrobial agents into polymers, such as tetracycline [32,33], antibiotic streptomycin sulfate [25] or where the polymer network acts as a transporter for the antibiotics, for usage as drug delivery systems. Polymer networks have also been combined with numerous metals with antimicrobial properties, such as zinc and silver, to deliver antimicrobial hydrogels [34-36]. Zinc has been recognized in numerous biological methods, being accountable for regulatory and structural systems in both eukaryotic and prokaryotic cells. It possesses antifungal, antiviral and antibacterial properties [37,38].

Based on the above literature reports and owing to the growing interest in the development of composites in a PAA matrix, we herein report the synthesis of different PAA-metal based composites that are modified with various pendant phenyl imide groups. The as-prepared PAA-based composites were characterized using various methods, such as scanning electron microscopy (SEM), X-ray powder diffraction (XRD), Fourier-transform infrared (FT-IR) spectroscopy, differential scanning calorimetry (DSC) and thermal gravimetric analysis (TGA). Furthermore, these composites have been evaluated for their antimicrobial properties against various pathogens.

\section{Results and Discussion}

\subsection{Scanning Electron Microscopy}

The surface morphology of the as-prepared PAA-based composites was further evaluated by scanning electron microscopy (SEM). The SEM images of different PAA-based composites are given in Figure 1, which were obtained at room temperature. It was observed that, morphologically, the composites possess well-defined and sharp edges; however, there is no consistency among the three composites tested. For example, Composite 6a exhibited a tiny rock-like morphology, while $\mathbf{6 b}$ appears to have a sheet/slab-like morphology with irregular stacking, whereas Composite $6 \mathrm{c}$ has shown a spherical bead-like morphology with no consistency in size, which is in the range of 0.5 to $2 \mu \mathrm{m}$. 

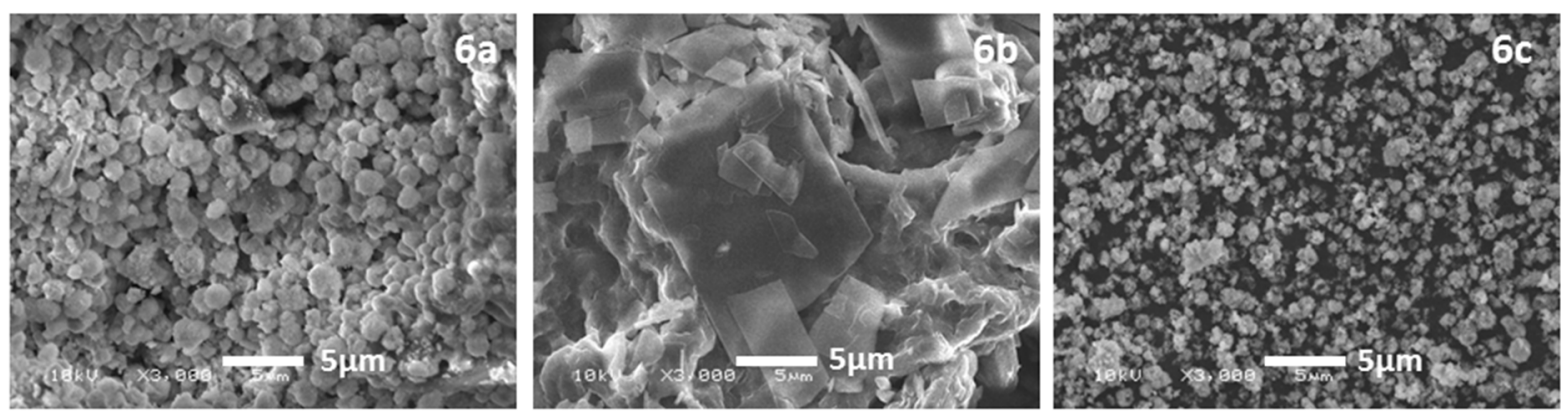

Figure 1. SEM micrographs of $6 a, 6 b$ and $6 c$.

\subsection{FT-IR Analysis}

The formation of various PAA-metal-based composites was monitored by FT-IR analysis. For this purpose, the FT-IR spectra of intermediated compounds polyacrylic acid 2 , amino phenol derivative of polyacrylic acid 3 and imides-modified compounds (5a to 5c) formed during the reaction, and the final composites were measured. For instance, the FT-IR spectrum of polyacrylic acid 2 consists of various peaks, which points towards the presence of the acrylic group, such as a peak located at $1710 \mathrm{~cm}^{-1}$ being attributed to the stretching vibration of the carbonyl group of carboxylic acid; the peak at $1402 \mathrm{~cm}^{-1}$ was attributed to the bending vibration of $-\mathrm{C}-\mathrm{H}$; and also, the occurrence of the peak at $1234 \mathrm{~cm}^{-1}$ was attributed the $\mathrm{C}-\mathrm{O}$ of acid or ester; whereas, the appearance of the new peaks in the range of 3360 to $3700 \mathrm{~cm}^{-1}$ belonging to the amino phenol in the IR spectrum of amino phenol derivative of polyacrylic acid 3 confirms the transformation of polyacrylic acid 2 to amino phenol derivative of polyacrylic acid 3. Apart from this, the IR spectrum of the amino phenol derivative of polyacrylic acid 3 also consists of some additional characteristics peaks, such as the peak at $2921 \mathrm{~cm}^{-1}$ was attributed the symmetrical stretching vibration of $\mathrm{C}-\mathrm{H}$ and aromatic $\mathrm{C}-\mathrm{H}$, and the peak at $1736 \mathrm{~cm}^{-1}$ appears to belong to the carbonyl group of carboxylic acid. In the spectra, the peaks at $1612 \mathrm{~cm}^{-1}, 1567 \mathrm{~cm}^{-1}, 1507 \mathrm{~cm}^{-1}$ and $1458 \mathrm{~cm}^{-1}$ were attributed to the stretching vibrations of $\mathrm{C}=\mathrm{C}$. The peak at $1355 \mathrm{~cm}^{-1}$ was attributed to the vibration of $-\mathrm{C}-\mathrm{H}$ - bending, and the peak at $1220 \mathrm{~cm}^{-1}$ was attributed to the stretching vibration of $\mathrm{C}-\mathrm{O}$ of the acid or ester. All of these peaks confirm the presence of both the amino phenol group, as well as the PAA back bone in the compound.

Furthermore, the FT-IR spectra of the imides-modified compounds (5a to $5 c$ ) is compared to the FT-IR spectra of zinc complexes of the imide derivative of polyacrylic acid (6a to $6 \mathbf{c}$ ) as shown in Figure $2 \mathrm{a}-\mathrm{c}$ to confirm the formation of the final composites. As per the literature, zinc is reported to produce a shift in the expected IR values by affecting the electron density in the bonded atoms and also has the capability to block out other prominent peaks [39]. Clearly, as shown in Figure 2a-c, some of the peaks are either missing from the spectra of final composites or they have slightly shifted from the original positions due to the addition of zinc. This confirms the presence of zinc in the final composites and also the formation of zinc complexes of the imide derivative of polyacrylic acid $\mathbf{6 a}$ to 6c. For instance, Figure $2 \mathrm{a}$ shows the IR spectra of $\mathbf{5 a}$ and $\mathbf{6 a}$. In the IR spectrum of $\mathbf{6 a}$, the peaks at 528 , $785,933,1071$ and $1327 \mathrm{~cm}^{-1}$ are missing, whereas some other peaks are slightly shifted, such as the peak at $1746 \mathrm{~cm}^{-1}$ belonging to the $\mathrm{C}=\mathrm{O}$ group; $1120 \mathrm{~cm}^{-1}$ related to the $\mathrm{N}-\mathrm{C}$ band stretching in $5 \mathbf{a}$ is slightly shifted to $1740 \mathrm{~cm}^{-1}$ and $1152 \mathrm{~cm}^{-1}$, respectively, in the IR spectrum of $6 \mathrm{a}$. Similar kinds of shifts are also observed in the IR spectra of $\mathbf{6 b}$ and $\mathbf{6 c}$, as shown in Figure $2 b, c$, respectively. The detail information of other prominent IR peaks of the Compounds $5 \mathbf{a}$ to $5 \mathbf{c}$ and $\mathbf{6 a}$ to $\mathbf{6 c}$ are given below. 

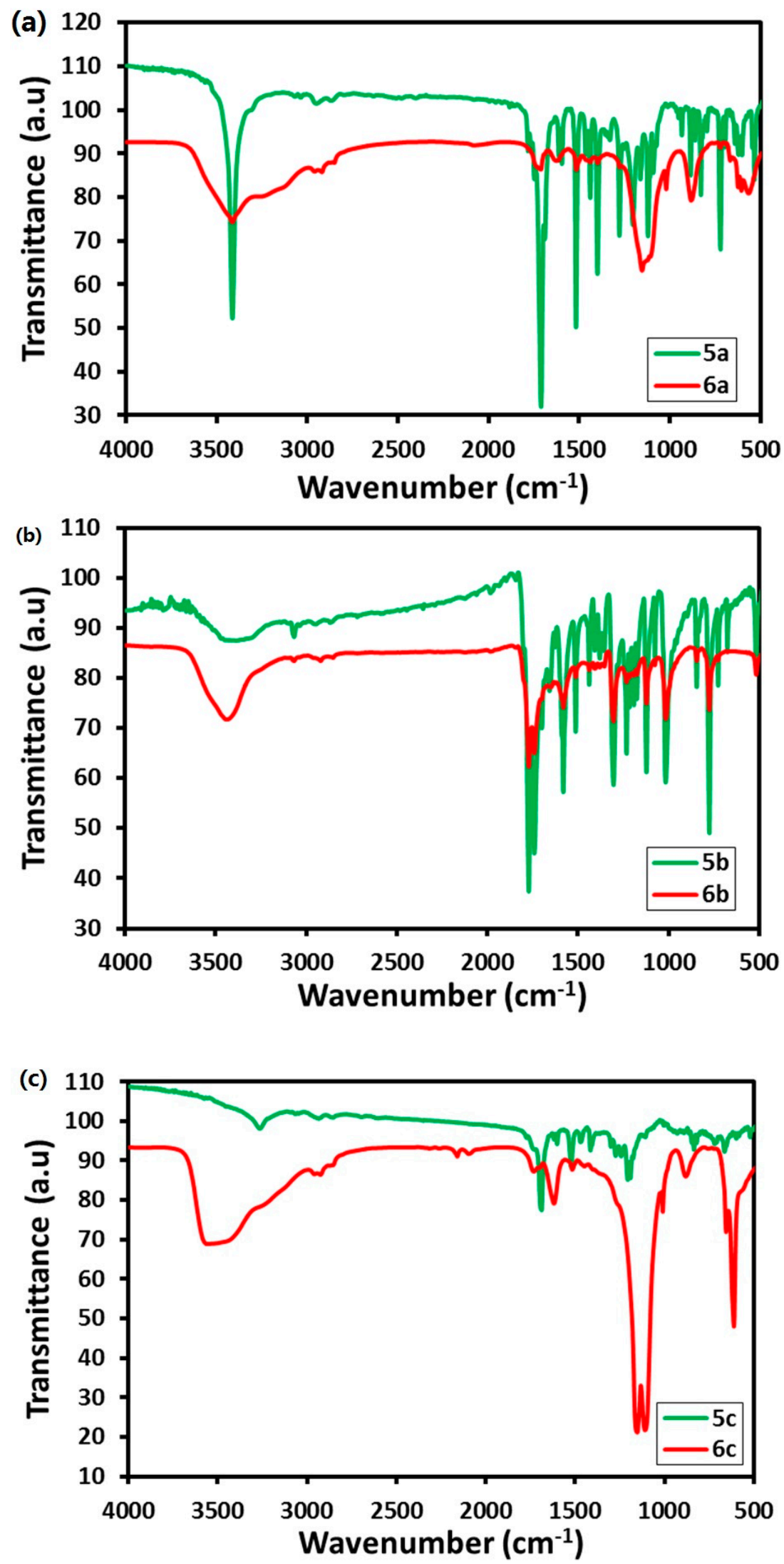

Figure 2. FT-IR spectra of $5 a$ and $6 a(a) ; 5 b$ and $6 b(b) ; 5 c$ and $6 c(c)$. 


\subsubsection{Imide Derivative of Polyacrylic Acids 5a to 5c}

5a: $v 3068 \mathrm{~cm}^{-1}$ (C-H aromatic and C-H stretching), $1748 \mathrm{~cm}^{-1}$ (C=O carboxylic acid), $1690 \mathrm{~cm}^{-1}$ $(\mathrm{C}=\mathrm{C}), 1611 \mathrm{~cm}^{-1}(\mathrm{C}=\mathrm{C}), 1595 \mathrm{~cm}^{-1}(\mathrm{C}=\mathrm{C}), 1518 \mathrm{~cm}^{-1}(\mathrm{C}=\mathrm{C}), 1399 \mathrm{~cm}^{-1}$ (-C-H- bending), $1278 \mathrm{~cm}^{-1}$ (C-O acid or ester), $1204 \mathrm{~cm}^{-1}$ (C-O acid or ester), $1120 \mathrm{~cm}^{-1}(\mathrm{~N}-\mathrm{C})$.

5b: $v 3066 \mathrm{~cm}^{-1}$ (C-H aromatic and C-H stretching), $1740 \mathrm{~cm}^{-1}$ (C=O carboxylic acid), $1699 \mathrm{~cm}^{-1}$ $(C=C), 1589 \mathrm{~cm}^{-1}(\mathrm{C}=\mathrm{C}), 1580 \mathrm{~cm}^{-1}(\mathrm{C}=\mathrm{C}), 1512 \mathrm{~cm}^{-1}(\mathrm{C}=\mathrm{C}), 1437 \mathrm{~cm}^{-1}(\mathrm{C}=\mathrm{C}), 1303 \mathrm{~cm}^{-1}(-\mathrm{C}-\mathrm{H}$ bending), $1231 \mathrm{~cm}^{-1}$ (C-O acid or ester), $1121 \mathrm{~cm}^{-1}(\mathrm{~N}-\mathrm{C})$.

5c: $v 3064 \mathrm{~cm}^{-1}$ (C-H aromatic and C-H stretching), $1769 \mathrm{~cm}^{-1}$ (C=O carboxylic acid), $1687 \mathrm{~cm}^{-1}$ $(C=C), 1600 \mathrm{~cm}^{-1}$ (C=C), $1522 \mathrm{~cm}^{-1}(\mathrm{C}=\mathrm{C}), 1469 \mathrm{~cm}^{-1}(\mathrm{C}=\mathrm{C}), 1413 \mathrm{~cm}^{-1}$ (-C-H bending), $1241 \mathrm{~cm}^{-1}$ (C-O acid or ester), $1205 \mathrm{~cm}^{-1}$ (C-O acid or ester), $1190 \mathrm{~cm}^{-1}(\mathrm{~N}-\mathrm{C})$.

\subsubsection{Zinc Complexes of the Imide Derivative of Polyacrylic Acid 6a to 6c}

6a: $v 2956 \mathrm{~cm}^{-1}$ (C-H aromatic and C-H stretching), $2866 \mathrm{~cm}^{-1}$ (C-H aromatic and C-H stretching), $1591 \mathrm{~cm}^{-1}(\mathrm{C}=\mathrm{C}), 1516 \mathrm{~cm}^{-1}(\mathrm{C}=\mathrm{C}), 1439 \mathrm{~cm}^{-1}(\mathrm{C}=\mathrm{C}), 1398 \mathrm{~cm}^{-1}$ (-C-H- bending), $1277 \mathrm{~cm}^{-1}(\mathrm{C}-\mathrm{O}$ acid or ester), $1152 \mathrm{~cm}^{-1}(\mathrm{~N}-\mathrm{C})$.

6b: $v 1740 \mathrm{~cm}^{-1}(\mathrm{C}=\mathrm{O}), 1580 \mathrm{~cm}^{-1}(\mathrm{C}=\mathrm{C}), 1511 \mathrm{~cm}^{-1}(\mathrm{C}=\mathrm{C}), 1437 \mathrm{~cm}^{-1}(\mathrm{C}=\mathrm{C}), 1407 \mathrm{~cm}^{-1}$ (-C-H- bending), $1353 \mathrm{~cm}^{-1}$ (-C-H bending), $1303 \mathrm{~cm}^{-1}$ (-C-H- bending), 1231 (C-O acid or ester), 1214 (C-O acid or ester), $1190 \mathrm{~cm}^{-1}$ (N-C), $1075 \mathrm{~cm}^{-1}$ (N-C), $1017 \mathrm{~cm}^{-1}$ (N-C).

6c: $v 1736 \mathrm{~cm}^{-1}(\mathrm{C}=\mathrm{O}), 1507 \mathrm{~cm}^{-1}(\mathrm{C}=\mathrm{C}), 1153 \mathrm{~cm}^{-1}(\mathrm{~N}-\mathrm{C}), 1020 \mathrm{~cm}^{-1}$ (N-C).

\section{3. ${ }^{1} \mathrm{H}-\mathrm{NMR}$ Analysis}

Additionally, the formation of zinc complexes of the imide derivative of polyacrylic acid from $6 \mathbf{6}$ to $\mathbf{6 c}$ is also confirmed by proton NMR, as shown in Figure 3, respectively. The ${ }^{1} \mathrm{H}-\mathrm{NMR}$ spectrum has given information about the presence of the polymeric back bone and the derivatization of the polymer along with the imides. The presence of the signals are in the aromatic region of the NMR $\delta$ ppm 6.5 to 8 . The presence of signals at the $\delta$ ppm 9.6 to 9.8 may be due to the presence of carboxylic acid groups on the polymeric chain, which could be due to incomplete derivatization. The detailed information of other prominent NMR signals of $\mathbf{5 a}$ to $\mathbf{5 c}$ and Composites $\mathbf{6 a}$ to $\mathbf{6 c}$ are given below. The ${ }^{1} \mathrm{H}-\mathrm{NMR}$ spectrum of Composites $\mathbf{6 a}$ to $\mathbf{6} \mathbf{c}$ are given in Figure 3.

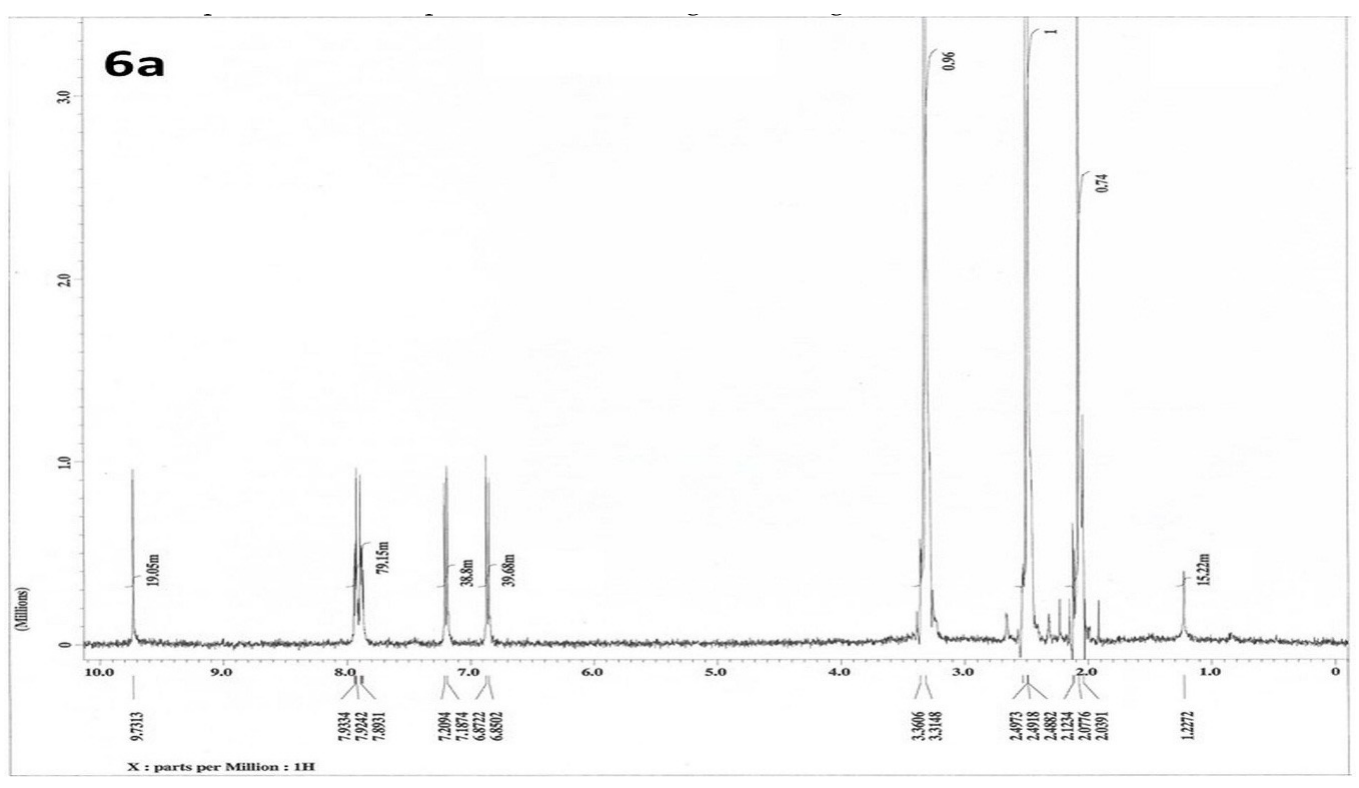

Figure 3. Cont. 

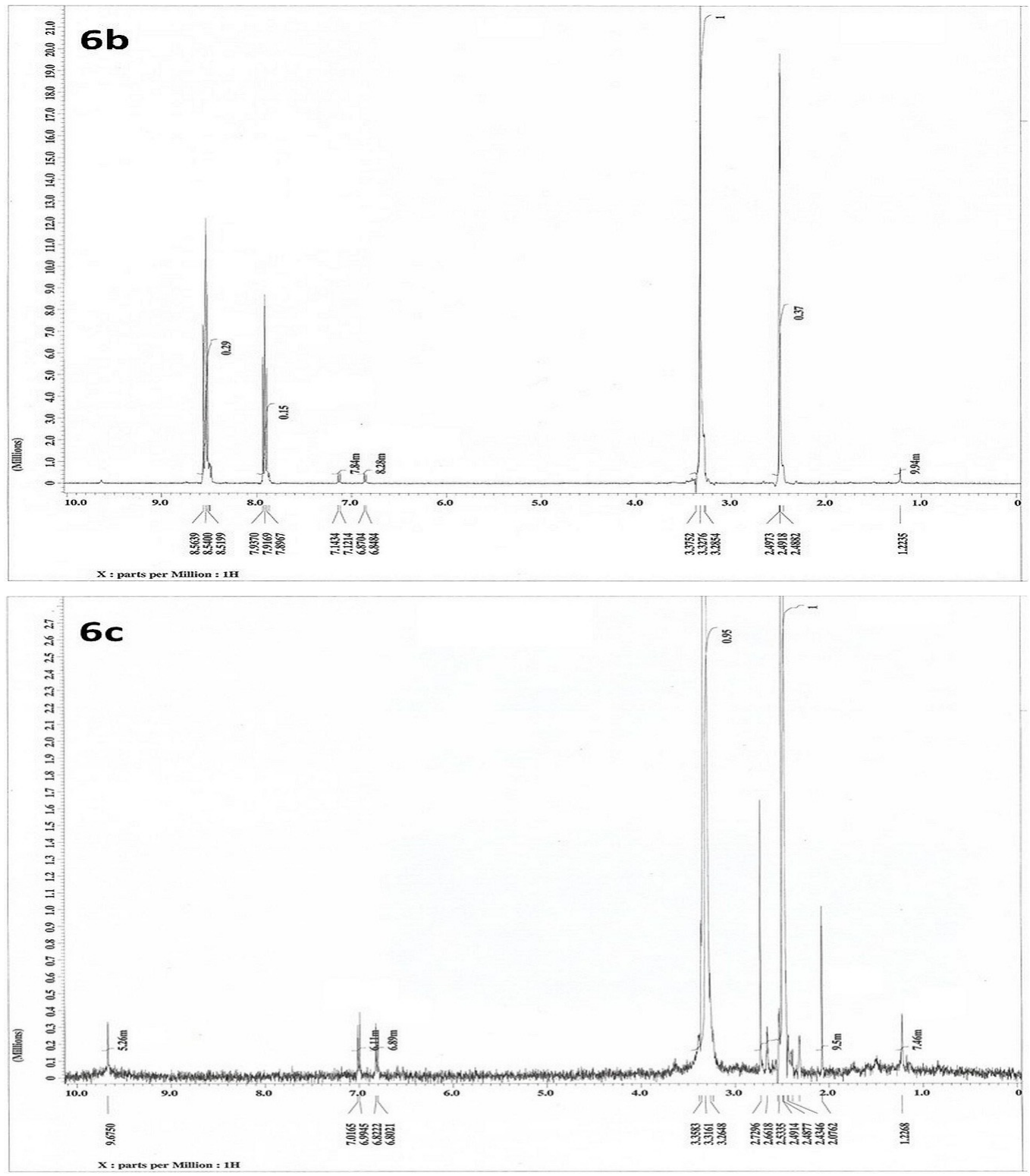

Figure $3 .{ }^{1} \mathrm{H}-\mathrm{NMR}$ spectrum of $\mathbf{6 a}, \mathbf{6 b}$ and $\mathbf{6 c}$.

Polyacrylic acid 2: ${ }^{1} \mathrm{H}-\mathrm{NMR}\left(400 \mathrm{MHz}, \mathrm{DMSO}-d_{6}\right): \delta \mathrm{ppm} 3.56(\mathrm{~s}, 10 \mathrm{H}), 7.09(\mathrm{~s}, 1 \mathrm{H})$.

Amino phenol derivative of polyacrylic acid $3:{ }^{1} \mathrm{H}-\mathrm{NMR}\left(400 \mathrm{MHz}, \mathrm{DMSO}-d_{6}\right): \delta \mathrm{ppm} 1.44-1.55$ $(\mathrm{m}, 2 \mathrm{H}), 3.36(\mathrm{t}, 9 \mathrm{H}), 6.61-6.81(\mathrm{dd}, 12 \mathrm{H}), 7.90(\mathrm{~s}, 1 \mathrm{H}), 9.12(\mathrm{~s}, 2 \mathrm{H})$.

\subsubsection{Imide Derivative of Polyacrylic Acids $5 \mathbf{a}$ to $5 \mathrm{c}$}

5a: ${ }^{1} \mathrm{H}-\mathrm{NMR}\left(400 \mathrm{MHz}, \mathrm{DMSO}-d_{6}\right): \delta$ ppm $3.34(\mathrm{~s}, 4 \mathrm{H}), 6.87(\mathrm{~d}, 2 \mathrm{H}), 7.21(\mathrm{~d}, 2 \mathrm{H}), 7.82$ to $8.00(\mathrm{~m}, 4 \mathrm{H})$, $9.74(\mathrm{~s}, 1 \mathrm{H})$.

5b: $:^{1} \mathrm{H}-\mathrm{NMR}\left(400 \mathrm{MHz}, \mathrm{DMSO}-d_{6}\right): \delta$ ppm 2.09 (s, 1H), 3.35 (s, 18H), $7.93(\mathrm{~s}, 2 \mathrm{H}), 8.54(\mathrm{~s}, 4 \mathrm{H})$.

5c: ${ }^{1} \mathrm{H}-\mathrm{NMR}\left(400 \mathrm{MHz}, \mathrm{DMSO}-d_{6}\right): \delta$ ppm 1.48 to $1.66(\mathrm{~m}, 1 \mathrm{H}), 1.7$ to $1.8(\mathrm{~m}, 1 \mathrm{H}), 2.74(\mathrm{~s}, 4 \mathrm{H}), 3.26$ to $3.44(\mathrm{~m}, 8 \mathrm{H}), 3.65(\mathrm{t}, 1 \mathrm{H}), 6.82(\mathrm{~d}, 2 \mathrm{H}), 7.01(\mathrm{~d}, 2 \mathrm{H}), 9.69(\mathrm{~s}, 1 \mathrm{H})$. 
2.3.2. Zinc Complexes of the Imide Derivative of Polyacrylic Acid $\mathbf{6 a}$ to $\mathbf{6 c}$

6a: ${ }^{1} \mathrm{H}-\mathrm{NMR}\left(400 \mathrm{MHz}\right.$, DMSO- $\left.d_{6}\right): \delta$ ppm $1.22(\mathrm{~s}, 1 \mathrm{H}), 6.85-6.87(\mathrm{~d}, 2 \mathrm{H}), 7.18-7.20(\mathrm{~d}, 2 \mathrm{H}), 7.89$ to 7.93 $(\mathrm{m}, 5 \mathrm{H}), 9.73(\mathrm{~s}, 1 \mathrm{H})$.

6b: ${ }^{1} \mathrm{H}-\mathrm{NMR}\left(400 \mathrm{MHz}\right.$, DMSO- $\left.d_{6}\right): \delta$ ppm $1.22(\mathrm{~s}, 1 \mathrm{H}), 6.84$ to $6.87(\mathrm{~d}, 1 \mathrm{H}), 7.12$ to $7.14(\mathrm{~d}, 1 \mathrm{H}), 7.89$ to $7.93(\mathrm{~m}, 20 \mathrm{H}), 8.51$ to $8.56(\mathrm{~m}, 40 \mathrm{H})$.

6c: ${ }^{1} \mathrm{H}-\mathrm{NMR}\left(400 \mathrm{MHz}, \mathrm{DMSO}-d_{6}\right): \delta$ ppm $1.22(\mathrm{~s}, 1 \mathrm{H}), 2.07$ (s, 2H), 6.80-6.82 (d, 1H), 6.99-7.01 (d, 1H), $9.67(\mathrm{~s}, 1 \mathrm{H})$.

\subsection{Thermo-Gravimetric Analysis}

TGA results for the polymers and their metal composite systems prepared in this study are shown in Figure 4. The polymers and their metal composites were subjected to heating up to $800{ }^{\circ} \mathrm{C}$ at the rate of $25^{\circ} \mathrm{C} / \mathrm{min}$. The results were compared, and it was observed that the metal composites were thermally more stable than their precursor. The weight loss at different temperatures is tabulated in Table 1.
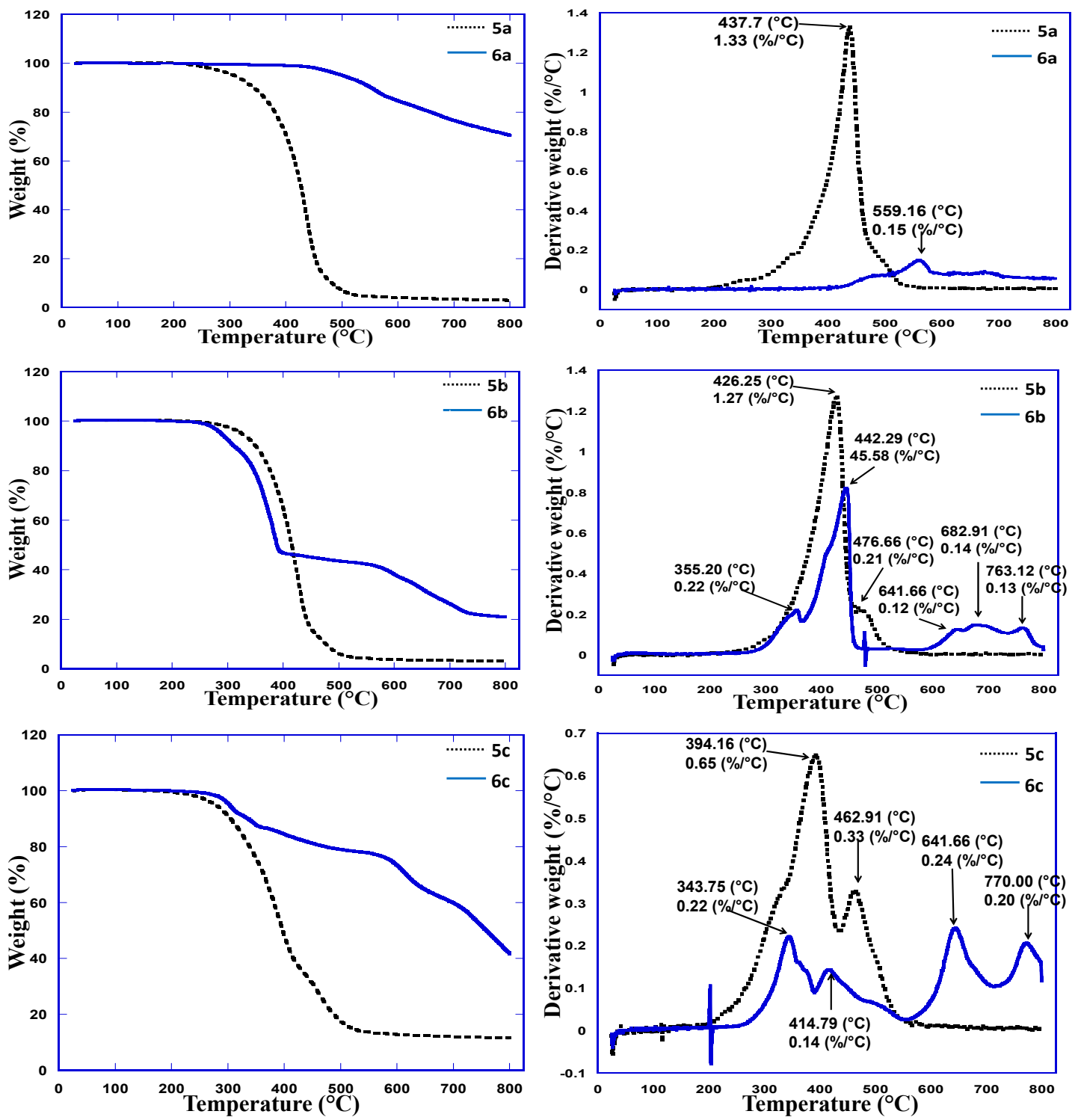

Figure 4. TGA graphs of $5 a$ and $6 a, 5 b$ and $6 b$ and $5 c$ and $6 c$. 
Table 1. Weight loss percentage for the polymers Compounds $5 \mathrm{a}$ to $5 \mathrm{c}$ and $\mathbf{6 a}$ to $6 \mathrm{c}$.

\begin{tabular}{cccccccc}
\hline \multirow{2}{*}{ Sample } & \multicolumn{7}{c}{ Weight Loss \% at Various Temperatures } \\
\cline { 2 - 8 } & $\mathbf{2 0 0}{ }^{\circ} \mathbf{C}$ & $\mathbf{3 0 0}{ }^{\circ} \mathbf{C}$ & $\mathbf{4 0 0}{ }^{\circ} \mathbf{C}$ & $\mathbf{5 0 0}{ }^{\circ} \mathbf{C}$ & $\mathbf{6 0 0}^{\circ} \mathbf{C}$ & $\mathbf{7 0 0}{ }^{\circ} \mathbf{C}$ & $\mathbf{8 0 0}^{\circ} \mathbf{C}$ \\
\hline $\mathbf{5 a}$ & 0 & 4.16 & 29.48 & 92.6 & 96.1 & 96.49 & 96.89 \\
$\mathbf{6 a}$ & 0 & 0.26 & 1.04 & 4.94 & 15.45 & 23.64 & 29.49 \\
$\mathbf{5 b}$ & 0 & 2.6 & 35.71 & 93.77 & 96.1 & 96.49 & 96.88 \\
$\mathbf{6 b}$ & 0 & 7.66 & 53.25 & 56.36 & 61.82 & 73.51 & 78.96 \\
$\mathbf{5 c}$ & 0.26 & 8.84 & 52.08 & 82.47 & 87.14 & 87.92 & 88.31 \\
$\mathbf{6 c}$ & 0 & 4.55 & 15.45 & 20.91 & 26.75 & 40.39 & 58.31 \\
\hline
\end{tabular}

\subsection{Differential Scanning Calorimetry}

DSC results for the polymers and their metal composite systems prepared in this study are shown in Figure 5. In order to further investigate the influence of $\mathrm{Zn}$ (II) complexation on the thermal property of the polymer, the differential scanning calorimetry studies were carried out for the polymer and the $\mathrm{Zn}$ (II) complex. From the thermogram of pure polymer, the melting point ( $\mathrm{Tm}$ ) of $\mathbf{5 a}$ to $\mathbf{5 c}$ was found at $302.4{ }^{\circ} \mathrm{C}, 269.16^{\circ} \mathrm{C}$ and $273.88^{\circ} \mathrm{C}$, respectively, while the metal complexes of the polymers $6 \mathbf{a}$ to $6 \mathbf{c}$, the melting point (Tm) was found to be $278.61{ }^{\circ} \mathrm{C}, 280.97^{\circ} \mathrm{C}$ and $277.43{ }^{\circ} \mathrm{C}$, respectively. This shift could be due to the interaction that occurs between the hydrophilic part of polymer and the $\mathrm{Zn}$ (II) metal ion and also gives an idea of the degree of complexation with the metal ion, which was found to be different for different polymers.
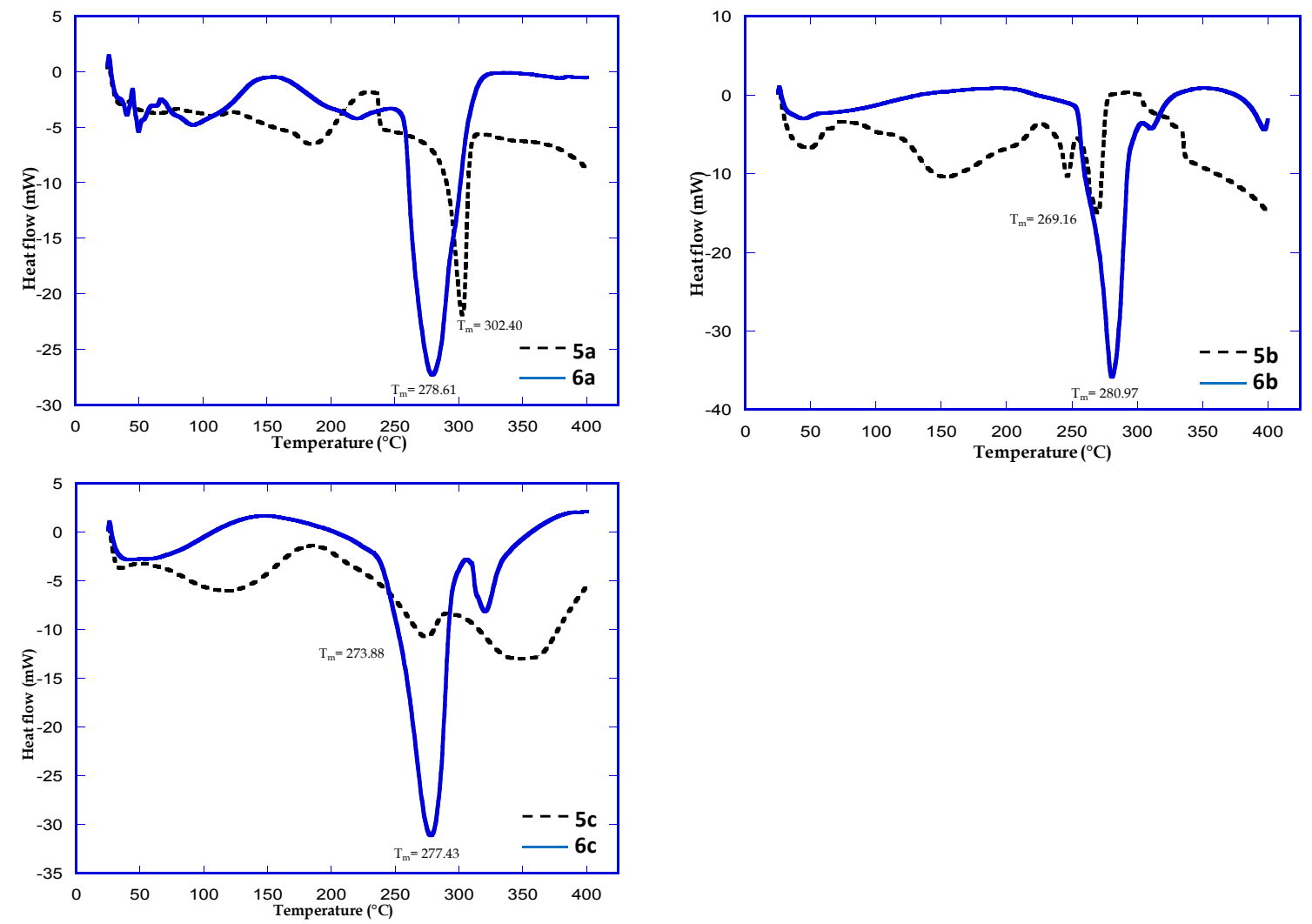

Figure 5. DSC spectra of polymer Compound $5 \mathbf{a}$ and $6 \mathbf{a}, 5 \mathbf{b}$ and $\mathbf{6 b}$ and $5 c$ and $6 c$. 


\subsection{Biological Evaluation}

\subsubsection{Antibacterial Activity}

The in vitro antibacterial activity of the newly-synthesized 6a to 6c (Shown in Table 2) has been studied against the bacterial strains Staphylococcus aureus (MTCC 96), Klebsiella planticola (MTCC 530), Bacillus subtilis (MTCC 121), S. aureus MLS16 (MTCC 2940), Micrococcus luteus (MTCC 2470), Escherichia coli (MTCC 739) and Pseudomonas aeruginosa (MTCC 2453) by the agar well diffusion method [40-42], and the strains were obtained from the Institute of Microbial Technology (IMTECH), Chandigarh. Neomycin was used as a standard drug.

Table 2. Antibacterial activity of zinc complexes of modified polyacrylic acid $\mathbf{6 a}, \mathbf{6 b}$ and $\mathbf{6 c}$.

\begin{tabular}{lcccc}
\hline \multirow{2}{*}{ Test Compounds $^{\mathbf{a}}$} & \multicolumn{4}{c}{ MIC $^{\mathbf{b}}(\boldsymbol{\mu g} / \mathbf{m L})$} \\
\cline { 2 - 5 } & $\mathbf{6 a}$ & $\mathbf{6 b}$ & $\mathbf{6 c}$ & Neomycin \\
\hline Staphylococcus aureus MTCC 96 & 300 & 18.75 & 18.75 & 18.75 \\
Klebsiella planticola MTCC 530 & 300 & 75 & 150 & 18.75 \\
Bacillus subtilis MTCC 121 & 75 & 75 & 37.5 & 18.75 \\
S. aureus MLS16 MTCC 2940 & 150 & 150 & 150 & 18.75 \\
Micrococcus luteus MTCC 2470 & 150 & 150 & 37.5 & 18.75 \\
Escherichia coli MTCC 739 & 150 & 150 & 75 & 18.75 \\
Pseudomonas aeruginosa MTCC 2453 & 150 & 75 & 75 & 18.75 \\
\hline = Microbial Type Culture Collection, Institute of & Microbial & Technology, Chandigarh, India;
\end{tabular}

The MIC values obtained from the following experiments were compared to neomycin as a standard, and it was observed that the Compounds $\mathbf{6 b}$ and $\mathbf{6 c}$ were found to be selectively active against Staphylococcus aureus MTCC 96 with biocidal activity equivalent to the standard used. The compounds have shown mild to very mild activity against the rest of the bacterial strains against which they were tested.

\subsubsection{Antifungal Activity}

The in vitro antifungal activity of the newly-synthesized 6a to 6c (Shown in Table 3) has been studied against the fungal strains Candida albicans (MTCC 227), Candida albicans (MTCC 854), Candida albicans (MTCC 1637), Candida albicans (MTCC 3017), Candida albicans (MTCC 3018), Candida albicans (MTCC 3958), Candida albicans (MTCC 4748), Candida albicans (MTCC 7315), Candida aaseri (MTCC 1962), Candida glabrata (MTCC 3019), Candida parapsilosis (MTCC 1744), Issatchenkia hanoiensis (MTCC 4755) and Issatchenkia orientalis (MTCC 3020) by the agar well diffusion method [40-42], and the strains were obtained from the Institute of Microbial Technology (IMTECH), Chandigarh. Fluconazole was used as a standard drug.

The MIC values obtained from the following experiments were compared to the fluconazole as a standard, and it was observed that the newly-synthesized compounds have exhibited mild to very mild activity against the fungal strains tested. The synthesized derivatives exhibited activity against fungal strain Issatchenkia orientalis comparable to the standard used.

Table 3. Antifungal activity of zinc complexes of modified polyacrylic acid $\mathbf{6 a}, \mathbf{6 b}$ and $\mathbf{6 c}$.

\begin{tabular}{lcccc}
\hline \multirow{2}{*}{ Test Compounds } & \multicolumn{4}{c}{ Minimum Inhibitory Concentration $(\boldsymbol{\mu g} / \mathbf{m L})$} \\
\cline { 2 - 5 } & $\mathbf{6 a}$ & $\mathbf{6 b}$ & $\mathbf{6 c}$ & Fluconazole \\
\hline Candida albicans MTCC 183 & 75 & 75 & 75 & 32 \\
Candida albicans MTCC 227 & 75 & 75 & 75 & 32 \\
Candida albicans MTCC 854 & 75 & 75 & 75 & 32 \\
\hline
\end{tabular}


Table 3. Cont.

\begin{tabular}{lcccc}
\hline \multirow{2}{*}{ Test Compounds } & \multicolumn{4}{c}{ Minimum Inhibitory Concentration $(\boldsymbol{\mu g} / \mathbf{m L})$} \\
\cline { 2 - 5 } & $\mathbf{6 a}$ & $\mathbf{6 b}$ & $\mathbf{6 c}$ & Fluconazole \\
\hline Candida albicans MTCC 1637 & 75 & 75 & 75 & 64 \\
Candida albicans MTCC 3017 & 75 & 75 & 75 & 64 \\
Candida albicans MTCC 3018 & 150 & 150 & 150 & 32 \\
Candida albicans MTCC 3958 & 75 & 75 & 75 & 64 \\
Candida albicans MTCC 4748 & 75 & 75 & 75 & 32 \\
Candida albicans MTCC 7315 & 75 & 75 & 75 & 32 \\
Candida aaseri MTCC 1962 & 150 & 150 & 150 & 64 \\
Candida glabrata MTCC 3019 & 150 & 150 & 150 & 64 \\
Candida parapsilosis MTCC 1744 & 150 & 150 & 150 & 16 \\
Issatchenkia hanoiensis MTCC 4755 & 300 & 300 & 300 & 128 \\
Issatchenkia orientalis MTCC 3020 & 150 & 150 & 150 & 128 \\
\hline
\end{tabular}

\section{Experimental Section}

\subsection{Materials and Strains}

Acrylic acid was purchased from Alpha Chemika, Mumbai, India, while ammonium peroxodisulfate and glacial acetic acid were procured from Qualikems, New Delhi, India. 4-amino phenol, succinic anhydride and thionyl chloride were purchased from BDH Chemicals Limited, Bristol, England. Zinc sulfate and phthalic anhydride were procured from Riedel-de Haen, Hanover, Germany, while cupric nitrate and naphthalic anhydride were from Fluka, Buchs, Switzerland. Solvents toluene, methanol and tetrahydrofuran were purchased from Panreac, Barcelona, Spain, and Merck, Darmstadt, Germany, respectively. All of the solvents were used as such without further purification.

\subsection{Methods}

\subsubsection{Synthesis of Polyacrylic Acid 2}

Polymerization of acrylic acid was carried out using the procedure reported earlier [43] in which ammonium peroxodisulfate was used to catalyze the reaction. Acrylic acid and ammonium peroxodisulfate were taken in 2:3 molar ratios. Ten milliliters ( 0.145 moles) of acrylic acid were dissolved in the least amount of toluene treated with aqueous solution of $41.5 \mathrm{~g}$ (0.2175 moles) of ammonium peroxodisulfate at $60^{\circ} \mathrm{C}$ for $6 \mathrm{~h}$. The pale yellow solid product obtained was isolated by vacuum filtration of the reaction mixture using a Buchner funnel. The precipitate was washed thoroughly with water to get rid of any excess catalyst or unreacted monomer that may be present in the precipitate formed. The pale yellow solid product obtained was dried in a vacuum oven at $70^{\circ} \mathrm{C}$. The product was confirmed by ${ }^{1} \mathrm{H}-\mathrm{NMR}$ studies.

\subsubsection{Synthesis of Amino Phenol Derivative of Polyacrylic Acid 3}

Polyacrylic acid was converted to corresponding acid chloride followed by coupling with 4-amino phenoxide (shown in Figure 6). Ten grams of polyacrylic acid were taken in a round bottomed flask, to which equimolar thionyl chloride was added, and the resulting solution was stirred for $48 \mathrm{~h}$ at room temperature in an inert atmosphere. This yielded the acid chloride derivative of the polyacrylic acid, which was further treated with sodium phenoxide, which was prepared by dissolving $23.9 \mathrm{~g}$ of 4 -amino phenol in a $1.5 \mathrm{M}$ solution of $8.8 \mathrm{~g}$ of sodium hydroxide and was stirred at room temperature for $30 \mathrm{~min}$. The black colored solid formed was filtered using the vacuum filtration process. This was washed several times with water and dilute $\mathrm{HCl}$. The obtained solid was dried in a vacuum oven at $70{ }^{\circ} \mathrm{C}$. The product was confirmed by ${ }^{1} \mathrm{H}-\mathrm{NMR}$ studies. 


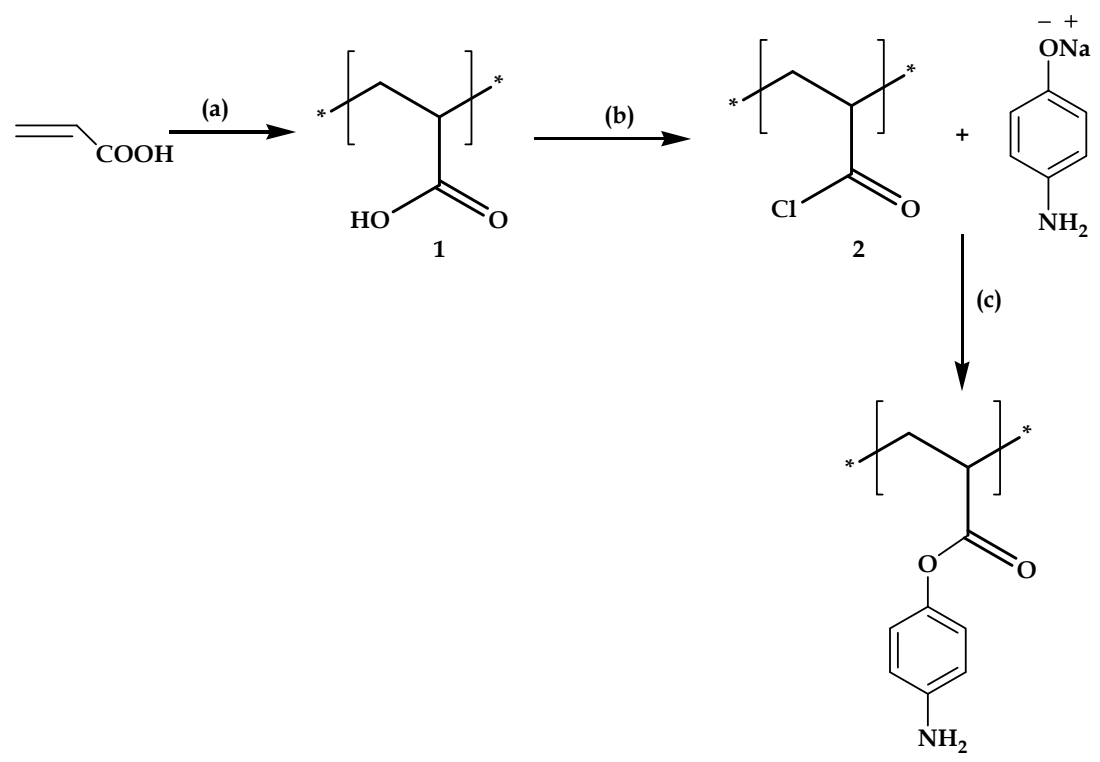

3

Figure 6. Synthesis of amino phenol derivative of polyacrylic acid 3. Reagents and conditions: (a) APS, toluene, $60^{\circ} \mathrm{C}, 6 \mathrm{~h}$; (b) $\mathrm{SOCl}_{2}, \mathrm{~N}_{2}, 48 \mathrm{~h}$; (c) aqueous $\mathrm{NaOH}, 4$-aminophenol, $30 \mathrm{~min}$.

\subsubsection{Synthesis of Imide Derivative of Polyacrylic Acids 5a to $\mathbf{5 c}$}

Imide Derivative of Polyacrylic Acids $\mathbf{5 a}$ to $\mathbf{5} \mathbf{c}$ is shown in Figure 7. Ten grams of $\mathbf{3}$ and equimolar anhydride were taken in a round bottom flask fitted with reflux condenser. In $100 \mathrm{~mL}$ acetic acid medium, the reaction mixture was refluxed for $5 \mathrm{~h}$. The black-colored solid formed was filtered using a vacuum filtration process, which was washed several times with water. The obtained solid was dried in a vacuum oven at $70{ }^{\circ} \mathrm{C}$. The product was confirmed by ${ }^{1} \mathrm{H}-\mathrm{NMR}$ studies.<smiles>CCCC=O</smiles>

$4 \mathrm{a}$<smiles>CC(C)(C)CC(C(=O)Oc1ccc(N)cc1)C(C)(C)C</smiles>

$4(\mathrm{a}-\mathrm{c})$

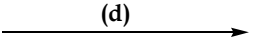

$\mathbf{R}=$<smiles>O=C1CC(=O)C(=O)O1</smiles><smiles>O=C1NC(=O)c2c[14cH]ccc21</smiles><smiles>[R]c1ccc(OC(=O)C(CC)C(C)(C)C)cc1</smiles>

$5(\mathrm{a}-\mathrm{c})$<smiles>O=C1NC(=O)c2cccc3cccc1c23</smiles><smiles>O=C1CCCC1</smiles>

Figure 7. Synthesis of imide derivative of polyacrylic acids $5 \mathbf{a}$ to $5 \mathrm{c}$. Reagents and conditions: (d) acetic acid, $130{ }^{\circ} \mathrm{C}$, reflux, $5 \mathrm{~h}$.

\subsubsection{Synthesis of Zinc Complexes of the Imide Derivative of Polyacrylic Acid $\mathbf{6 a}$ to $\mathbf{6 c}$}

The zinc composite of the desired structure was made using zinc sulfate heptahydrate (shown in Figure 8). Five hundred milligrams of the amide derivative of PAA, dissolved in $5 \mathrm{~mL}$ of tetrahydrofuran, were mixed with an equimolar quantity of zinc salt solution, which was made by dissolving $3 \mathrm{~mL}$ of methanol, with constant stirring for $20 \mathrm{~min}$. The product obtained was separated using vacuum filtration using a Buchner funnel, washed several times with distilled water and dried at $70^{\circ} \mathrm{C}$. The yield is $262 \mathrm{mg}$. 


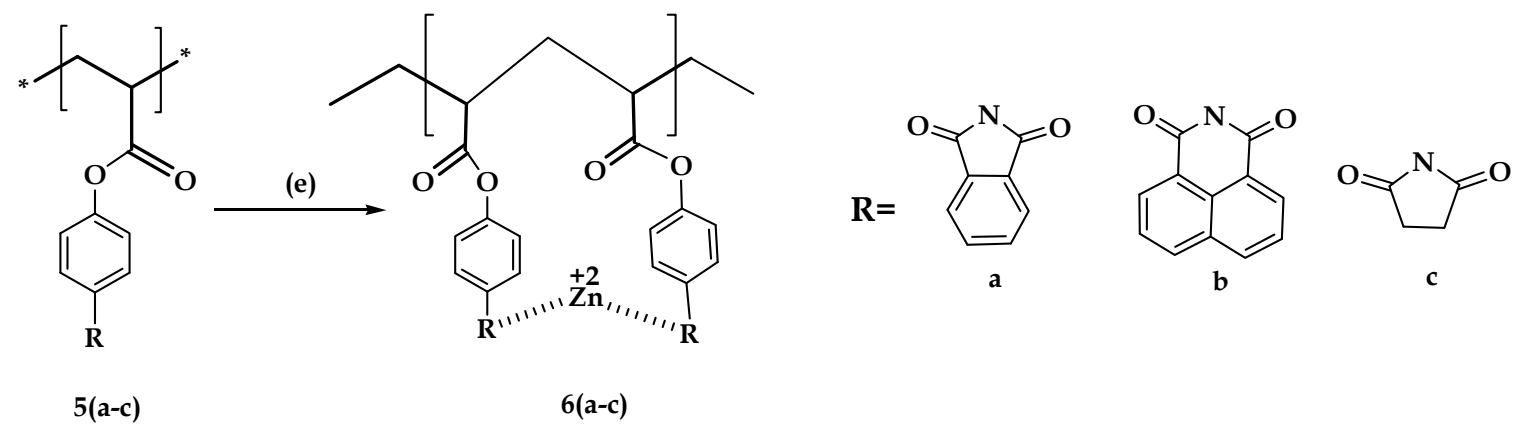

Figure 8. Synthesis of zinc complexes of the imide derivative of polyacrylic acid $\mathbf{6 a}$ to $\mathbf{6 c}$. Reagents and conditions: (e) Zinc sulfate heptahydrate, $\mathrm{CH}_{3} \mathrm{OH}$, THF, $20 \mathrm{~min}$.

\subsection{Methods of Characterization}

Powder X-ray diffraction (XRD) studies were carried out using an Altima IV Regaku X-ray diffractometer. Fourier transform infrared spectra (FT-IR) were recorded on a Perkin-Elmer spectrum 1000 FT-IR spectrophotometer. ${ }^{1}$ H-NMR spectra were obtained on an automated JEOL Eclipse-400 spectrometer in dimethyl sulphoxide- $d_{6}$. Thermal gravimetric analysis (TGA) was measured on a Mettler Toledo TGA1 and differential scanning calorimetry (DSC) was measured on a Mettler Toledo DSC1. TGA was done in the temperature range of 25 to $800{ }^{\circ} \mathrm{C}$ in nitrogen gas, whereas DSC a range of 25 to $400{ }^{\circ} \mathrm{C}$. Approximately $7 \mathrm{mg}$ of sample were taken in this study.

\subsection{Method of Antimicrobial Activity}

Bacterial and Fungal Strains

For determining the antimicrobial activity, the following strains of bacteria and fungi were used. All of the strains were obtained from the Microbial Type Culture Collection (MTCC). Staphylococcus aureus (MTCC 96), Klebsiella planticola (MTCC 530), Bacillus subtilis (MTCC 121), S. aureus MLS16 (MTCC 2940), Micrococcus luteus (MTCC 2470), Escherichia coli (MTCC 739), Pseudomonas aeruginosa (MTCC 2453). Candida albicans (MTCC 227), Candida albicans (MTCC 854), Candida albicans (MTCC 1637), Candida albicans (MTCC 3017), Candida albicans (MTCC 3018), Candida albicans (MTCC 3958), Candida albicans (MTCC 4748), Candida albicans (MTCC 7315), Candida aaseri (MTCC 1962), Candida glabrata (MTCC 3019), Candida parapsilosis (MTCC 1744), Issatchenkia hanoiensis (MTCC 4755), Issatchenkia orientalis (MTCC 3020).

For growing the strains, the recommended medium was used and for long-term preservation. Strains were stored at $-80^{\circ} \mathrm{C}$ in $20 \%$ glycerol.

Antibacterial activity of the composites was tested using the standard agar diffusion method [40-42]. Cultures of bacteria were grown to log phase in their respective recommended medium. These cultures were mixed with sterile soft agar, and the mixture was subsequently poured on the surface of respective agar plates. Wells were created in the agar using a sterile borer. Finally, the materials to be tested were added to the wells, and plates were incubated at temperatures recommended for bacteria for optimal growth. The zone of inhibition was measured using a scale and was recorded after 2 to 3 days of incubation.

The antifungal activity against various species of Candida was also determined by using the standard agar diffusion method, as described above, except that the Sabouraud dextrose agar medium was used.

\section{Conclusions}

This work explores the new derivatives of polyacrylic acid, a well-known polymer, designed and synthesized with the aim to improve and enhance its properties. The synthesized derivatives were found to possess a varied degree of complexation with the metal salt based on the DSC results and 
better thermal stability on the TGA analysis. The biological evaluation revealed that the displayed zinc derivative of one polymer was found to possess excellent activity against Staphylococcus aureus bacterial strain, while moderate to mild activity against the bacterial strains tested, while it displayed mild activity against the fungal strains tested.

Acknowledgments: The authors would like to extend their sincere appreciation to the Deanship of Scientific Research at King Saud University for its funding this research group, No. RG-1436-032. The authors extend their gratitude to Ahmed Kamal and his group for helping us with carrying out the biological studies of the nanocomposites.

Author Contributions: S.F.A. and M.Kh. designed the project. M.R.S. and S.F.A. helped to draft the manuscript. M.Ku. and M.R.S carried out the experimental part of polyacrylic acid-zinc complexes and some part of the characterization. N.A. carried out some of the characterizations. S.F.A., M.R.S. and M.Kh. carried out interpretation of the results. A.A.-W. and M.R.H.S. provided scientific guidance for successful completion of the project and helped to draft the manuscript. All authors read and approved the final manuscript.

Conflicts of Interest: The authors declare no conflict of interest.

\section{References}

1. Patil, D.S.; Pawar, S.A.; Devan, R.S.; Gang, M.G.; Ma, Y.-R.; Kim, J.H.; Patil, P.S. Electrochemical supercapacitor electrode material based on polyacrylic acid/polypyrrole/silver composite. Electrochim. Acta 2013, 105, 569-577. [CrossRef]

2. Guo, T.-F.; Chang, S.-C.; Pyo, S.; Yang, Y. Vertically integrated electronic circuits via a combination of self-assembled polyelectrolytes, ink-jet printing, and electroless metal plating processes. Langmuir 2002, 18, 8142-8147. [CrossRef]

3. Li, L.; Zhang, L.; Wang, T.; Wu, X.; Ren, H.; Wang, C.; Su, Z. Facile and scalable synthesis of novel spherical au nanocluster assemblies@ polyacrylic acid/calcium phosphate nanoparticles for dual-modal imaging-guided cancer chemotherapy. Small 2015, 11, 3162-3173. [CrossRef] [PubMed]

4. Popelka, A.; Novák, I.; Lehocký, M.; Chodák, I.; Sedliačik, J.; Gajtanska, M.; Sedliačiková, M.; Vesel, A.; Junkar, I.; Kleinová, A. Anti-bacterial treatment of polyethylene by cold plasma for medical purposes. Molecules 2012, 17, 762-785. [CrossRef] [PubMed]

5. Craciun, G.; Ighigeanu, D.; Manaila, E.; Stelescu, M.D. Synthesis and characterization of poly (acrylamide-co-acrylic acid) flocculant obtained by electron beam irradiation. Mater. Res. 2015, 18, 984-993. [CrossRef]

6. Couto, D.; Sousa, R.; Andrade, L.; Leander, M.; Lopez-Quintela, M.A.; Rivas, J.; Freitas, P.; Lima, M.; Porto, G.; Porto, B. Polyacrylic acid coated and non-coated iron oxide nanoparticles are not genotoxic to human Tymphocytes. Toxicol. Lett. 2015, 234, 67-73. [CrossRef] [PubMed]

7. Liu, Y.; Liu, Y.; Lee, J.-H.; Lee, C.; Park, M.; Kim, H.-Y. Ultrafine formation of optically transparent polyacrylonitrile/polyacrylic acid nanofibre fibrils via electrospinning at high relative humidity. Compos. Sci. Technol. 2015, 117, 404-409. [CrossRef]

8. Yamaguchi, H.; Nakanishi, S.; Iba, H.; Itoh, T. Amorphous polymeric anode materials from poly (acrylic acid) and tin (ii) oxide for lithium ion batteries. J. Power Sources 2015, 275. [CrossRef]

9. Wang, Y.; Wang, X.; Tang, S.; Vongehr, S.; Syed, J.A.; Meng, X. Highly processible and electrochemically active graphene-doped polyacrylic acid/polyaniline allowing the preparation of defect-free thin films for solid-state supercapacitors. RSC Adv. 2015, 5, 62670-62677. [CrossRef]

10. Huang, Y.; Zhong, M.; Huang, Y.; Zhu, M.; Pei, Z.; Wang, Z.; Xue, Q.; Xie, X.; Zhi, C. A self-healable and highly stretchable supercapacitor based on a dual crosslinked polyelectrolyte. Nat. Commun. 2015, 6. [CrossRef]

11. Chandrasekara, N.; Pashley, R. Study of a new process for the efficient regeneration of ion exchange resins. Desalination 2015, 357, 131-139. [CrossRef]

12. Dharmalingam, V.; Sahayaraj, P.A.; Amalraj, A.J.; Shobana, R.; Mohan, R. The corrosion inhibition performance of polyacrylic acid with potassium sodium tartrate and $\mathrm{Zn}^{2+}$ for corrosion control of mild steel in aqueous solution. Int. Lett. Chem. Phys. Astron. 2015, 61, 135-146. [CrossRef]

13. Xu, X.; Bai, B.; Ding, C.; Wang, H.; Suo, Y. Synthesis and properties of an ecofriendly superabsorbent composite by grafting the poly (acrylic acid) onto the surface of dopamine-coated sea buckthorn branches. Ind. Eng. Chem. Res. 2015, 54, 3268-3278. [CrossRef] 
14. López-Ortiz, A.; Collins-Martínez, V.H.; Hernández-Escobar, C.A.; Flores-Gallardo, S.G.; Zaragoza-Contreras, E.A. Protection of nio nanoparticles against leaching in acid medium by grafting of polyacrylic acid. Mater. Chem. Phys. 2008, 109, 306-310.

15. Patel, R.; Jung, Y.E.; Kim, D.J.; Kim, S.J.; Kim, J.H. Poly (ethylene-co-acrylic acid)-g-poly (ethylene glycol) graft copolymer templated synthesis of mesoporous $\mathrm{TiO}_{2}$ thin films for quasi-solid-state dye sensitized solar cells. Thin Solid Films 2014, 552, 68-74. [CrossRef]

16. Yan, J.; Huang, Y.; Miao, Y.-E.; Tjiu, W.W.; Liu, T. Polydopamine-coated electrospun poly (vinyl alcohol)/poly (acrylic acid) membranes as efficient dye adsorbent with good recyclability. J. Hazard. Mater. 2015, 283, 730-739. [CrossRef] [PubMed]

17. Godnjavec, J.; Znoj, B.; Vince, J.; Steinbucher, M.; Žnidaršič, A.; Venturini, P. Stabilization of rutile $\mathrm{TiO}_{2}$ nanoparticles with glymo in polyacrylic clear coating. Mater. Technol. 2012, 46, 19-24.

18. Pena, J.; Vallet-Regi, M.; Román, J.S. $\mathrm{TiO}_{2}$-polymer composites for biomedical applications. J. Biomed. Mater. Res. 1997, 35, 129-134. [PubMed]

19. Tokuhisa, H.; Hammond, P.T. Solid-state photovoltaic thin films using $\mathrm{TiO}_{2}$, organic dyes, and layer-by-layer polyelectrolyte nanocomposites. Adv. Funct. Mater. 2003, 13, 831-839.

20. Li, S.; Wang, H.; Huang, W.; Liu, X. Facile preparation of ph-sensitive poly(acrylic acid-co-acrylamide) $/ \mathrm{SiO} 2$ hybrid hydrogels with high strength by in situ frontal polymerization. Colloid Polym. Sci. 2014, 292, 107-113. [CrossRef]

21. Shahid, S.A.; Qidwai, A.A.; Anwar, F.; Ullah, I.; Rashid, U. Improvement in the water retention characteristics of sandy loam soil using a newly synthesized poly (acrylamide-co-acrylic acid)/ $\mathrm{AlZnFe}{ }_{2} \mathrm{O}_{4}$ superabsorbent hydrogel nanocomposite material. Molecules 2012, 17, 9397-9412. [CrossRef] [PubMed]

22. Ejima, H.; Richardson, J.J.; Liang, K.; Best, J.P.; van Koeverden, M.P.; Such, G.K.; Cui, J.; Caruso, F. One-step assembly of coordination complexes for versatile film and particle engineering. Science 2013, 341, 154-157. [PubMed]

23. Liang, K.; Ricco, R.; Doherty, C.M.; Styles, M.J.; Bell, S.; Kirby, N.; Mudie, S.; Haylock, D.; Hill, A.J.; Doonan, C.J. Biomimetic mineralization of metal-organic frameworks as protective coatings for biomacromolecules. Nat. Commun. 2015, 6. [CrossRef]

24. Liang, K.; Richardson, J.J.; Ejima, H.; Such, G.K.; Cui, J.; Caruso, F. Peptide-tunable drug cytotoxicity via one-step assembled polymer nanoparticles. Adv. Mater. 2014, 26, 2398-2402. [PubMed]

25. Nurkeeva, Z.S.; Khutoryanskiy, V.V.; Mun, G.A.; Sherbakova, M.V.; Ivaschenko, A.T.; Aitkhozhina, N.A. Polycomplexes of poly(acrylic acid) with streptomycin sulfate and their antibacterial activity. Eur. J. Pharm. Biopharm. 2004, 57, 245-249. [CrossRef]

26. Gottenbos, B.; Grijpma, D.W.; van der Mei, H.C.; Feijen, J.; Busscher, H.J. Antimicrobial effects of positively charged surfaces on adhering gram-positive and gram-negative bacteria. J. Antimicrob. Chemother. 2001, 48, 7-13. [PubMed]

27. Gottenbos, B.; van der Mei, H.C.; Klatter, F.; Grijpma, D.W.; Feijen, J.; Nieuwenhuis, P.; Busscher, H.J. Positively charged biomaterials exert antimicrobial effects on gram-negative bacilli in rats. Biomaterials 2003, 24, 2707-2710. [CrossRef]

28. Popelka, A.; Novák, I.; Lehocký, M.; Junkar, I.; Mozetič, M.; Kleinová, A.; Janigová, I.; Šlouf, M.; Bílek, F.; Chodák, I. A new route for chitosan immobilization onto polyethylene surface. Carbohydr. Polym. 2012, 90, 1501-1508. [PubMed]

29. Ping, X.; Wang, M.; Xuewu, G. Surface modification of poly (ethylene terephthalate)(PET) film by gamma-ray induced grafting of poly (acrylic acid) and its application in antibacterial hybrid film. Radiat. Phys. Chem. 2011, 80, 567-572. [CrossRef]

30. Mosleh, S.; Gawish, S.; Khalil, F.; Bieniek, R. Properties and application of novel amphoteric polypropylene fabrics. J. Appl. Polym. Sci. 2005, 98, 2373-2379.

31. Yang, J.M.; Lin, H.T.; Wu, T.H.; Chen, C.C. Wettability and antibacterial assessment of chitosan containing radiation-induced graft nonwoven fabric of polypropylene-g-acrylic acid. J. Appl. Polym. Sci. 2003, 90, 1331-1336. [CrossRef]

32. Bajpai, A.K.; Mishra, A. Preparation and characterization of tetracycline-loaded interpenetrating polymer networks of carboxymethyl cellulose and poly (acrylic acid): Water sorption and drug release study. Polym. Int. 2005, 54, 1347-1356. [CrossRef] 
33. Koneru, B.; Shi, Y.; Wang, Y.-C.; Chavala, S.H.; Miller, M.L.; Holbert, B.; Conson, M.; Ni, A.; di Pasqua, A.J. Tetracycline-containing MCM-41 mesoporous silica nanoparticles for the treatment of Escherichia coli. Molecules 2015, 20, 19690-19698. [CrossRef] [PubMed]

34. Pahontu, E.; Fala, V.; Gulea, A.; Poirier, D.; Tapcov, V.; Rosu, T. Synthesis and characterization of some new $\mathrm{Cu}$ (II), Ni (II) and Zn (II) complexes with salicylidene thiosemicarbazones: Antibacterial, antifungal and in vitro antileukemia activity. Molecules 2013, 18, 8812-8836. [CrossRef] [PubMed]

35. Voronkov, M.; Antonik, L.; Kogan, A.; Lopyrev, V.; Fadeeva, T.; Marchenko, V.; Abzaeva, K. Antimicrobial and hemostatic effects of silver salts of poly (acrylic acid). Pharm. Chem.J. 2002, 36, 26-28.

36. Abzaeva, K.; Voronkov, M.; Zhilitskaya, L.; Belozerskaya, G.; Makarov, V. Pharmacological properties of poly (zinc acrylate) ziacryl. Dokl. Biol. Sci. 2009, 424, 1-2. [CrossRef] [PubMed]

37. Yamamoto, O. Influence of particle size on the antibacterial activity of zinc oxide. Int. J. Inorg. Mater. 2001, 3, 643-646. [CrossRef]

38. Palza, H. Antimicrobial polymers with metal nanoparticles. Int. J. Mol. Sci. 2015, 16, 2099-2116. [CrossRef] [PubMed]

39. Saha, J.; Podder, J. Crystallization of zinc sulphate single crystals and its structural, thermal and optical characterization. J. Bangladesh Acad. Sci. 2011, 35, 203-210.

40. Goldman, E.; Green, L.H. Practical Handbook of Microbiology; CRC Press: Boca Raton, FL, USA, 2015.

41. Perez, C.; Pauli, M.; Bazerque, P. An antibiotic assay by the agar well diffusion method. Acta Biol. Med. Exp. 1990, 15, 113-115.

42. Kalemba, D.; Kunicka, A. Antibacterial and antifungal properties of essential oils. Curr. Med. Chem. 2003, 10, 813-829. [PubMed]

43. Shumaila; Lakshmi, G.B.V.S.; Alam, M.; Siddiqui, A.M.; Zulfequar, M.; Husain, M. Synthesis and characterization of Se doped polyaniline. Curr. Appl. Phys. 2011, 11, 217-222. [CrossRef]

Sample Availability: Samples of the compounds are not available from the authors.

(C) 2016 by the authors; licensee MDPI, Basel, Switzerland. This article is an open access article distributed under the terms and conditions of the Creative Commons by Attribution (CC-BY) license (http://creativecommons.org/licenses/by/4.0/). 